\title{
Lăsați-mă să cânt! [Let me sing!] - a Romanian operetta by Gherase Dendrino: links between the ethical, aesthetic and political content
}

\author{
TATIANA OLTEAN \\ "Gheorghe Dima" Music Academy Cluj-Napoca \\ ROMANIA*
}

\begin{abstract}
It was during the communist regime of the post-war years that Romanian composer Gherase Dendrino wrote an operetta in celebration of the centenary of Ciprian Porumbescu's birth, named Lăsați-mă să cânt [Let me sing!]. It revolves around the figure of Porumbescu himself, as the first Romanian composer to have ever written an operetta that would be performed and published, named Crai nou [New Moon]. Lăsați-mă să cânt [Let me sing!] tells the story of the making of the first Romanian operetta and was revived during the spring of 2018 at the Cluj-Napoca Romanian National Opera House, as part of the festivities related to the Centenary of the Great Union. The present research highlights three aspects of Dendrino's operetta: firstly, the one related to the ethical values, epitomized in the libretto by the main character, Ciprian, who, along with his friends, achieves the greatest task of the birth of the Romanian operetta, in spite of all opposition and pitfalls; secondly, the aesthetic content, regarding de musical language of the work, opposing the world of the Romanian provincial town to the Viennese Salonmusik; thirdly, the political aspect, encompassing the subtext of the libretto and the message of the work, which underwent continuous changes over the decades and social and political contexts up to the present day. Thus, the analysis takes into account both the sound and the word.
\end{abstract}

Keywords: Romanian, operetta, ethical, aesthetical, political.

\section{Introduction}

In $1953^{1}$, Romanian composer Gherase Dendrino ${ }^{2}$ wrote an anniversary operetta named Lăsați-mă să cânt [Let me sing!], in celebration of the Centenary of

\footnotetext{
*taania18@yahoo.com

${ }^{1}$ The operetta, set in three acts and subsequently revised in two acts, premiered in Bucharest on the $30^{\text {th }}$ of October 1954, at the Operetta Theater, under the baton of the composer. The libretto was devised by Erastia Sever, Liliana Delescu and Viorel Cosma and later translated into German, Czech, Russian, Hungarian and also premiered in East-European cultural cities as Dresda (The Democratic Republic of Germany), 1956, Olomouc (Czechoslovakia) 1957, Odessa (The USSR) 1957.

${ }^{2}$ Gherase Dendrino (b. 1901, Turnu Măgurele, Romania - d. 1973, Bucharest, Romania) was a Romanian composer and conductor. He studied composition at the "Ciprian Porumbescu" Conservatory in Bucharest under the tutorship of Dumitru Georgescu Kiriac and Alfonso Castaldi. He is acclaimed for his stage works (operettas such as Let me sing! and Lysistrata); he also wrote film music and popular songs. There is a vast array of performers of his songs, many
} 
Ciprian Porumbescu's birth ${ }^{3}$. The plot was set in Brașov, a central provincial Romanian town, in 1882, during the last year of the young composer's life, around the days of the premiere of his operetta: Crai Nou [New Moon] ${ }^{4}$ (Cosma, 1999, p. 177).

As the Centenary of the Great Union Day of $1918^{5}$ drew near, the Opera House in Brașov staged a new production of Porumbescu's New Moon. In its turn, The Romanian National Opera House in Cluj-Napoca programmed a new production of Gherase Dendrino's operetta: Let me sing!. It was going to be an event full of significance not only in view of the content of the work but, moreover, in that of the unfolding of events during the preparation of the new production. Thus, theatre director Cătălin Ionescu-Arbore was appointed, son of Anghel I. Arbore, who was, in his turn, a famous Romanian director who had been in charge of the first premiere of Let me sing! in Cluj ${ }^{6}$ (Cosma, 2010,

of them renowned Romanian singers such as Gică Petrescu, Mia Braia, Doina Badea, Jean Moscopol. His musical style was influenced by folk idioms and by light genres like the romance and the tango.

${ }^{3}$ Ciprian Porumbescu (born as Ciprian Gołębiowski, 1853, Șipotele Sucevei, d. 1883, Stupca) is one of the most iconic figures of the second half of the $19^{\text {th }}$ Century Romanian School of composition. A renowned violinist and composer, Porumbescu studied composition in Vienna under Anton Bruckner. He wrote works that are still widely spread and well-known to the Romanian audience, such as the Balada pentru vioară şi orchestră [Ballad for violin and orchestra] op. 29, as well as patriotic songs and choral pieces; let us not forget his most acclaimed creation, an operetta called New Moon [Crai nou], was the first Romanian operetta to be premiered in Brașov (Romania) in 1882, just a few months prior to the composer's premature death. He is also known for his patriotic chorus 'Union! is written on our flag! [Pe-al nostru steag e scris 'Unire!'] which has been used by Albania as its national anthem since 1912.

4 The New Moon is generally regarded as one of the four phases of the Moon. As well as Romanian folk is concerned, however, the New Moon is a symbol of pure love and good luck. At night, throughout a new moon, it is believed that young maidens invoking the new moon would dream their husbands-to-be. It is also believed that bad luck will be pushed away at midnight during a new moon.

${ }^{5}$ In 1859, Alexandru Ioan Cuza was elected to rule over both Moldavia and Wallachia; at the time, the two main Romanian principalities were still vassals of the Ottoman Empire until the Independence War of 1877-1878; thus, Cuza contributed to the creation of modern Romania, and historiographers refer to this major event as "The Little Union", while Transylvania, the third Romanian main principality, was still part of the Austrian Empire. Romania became a kingdom in 1881, under the rule of King Carol I of the royal family of HohenzollernSigmaringen. Following the First World War, in 1918, Transylvania, along with Bukovina (currently divided between Romania and Ukraine) and Eastern Moldavia (historical Romanian province fallen under Russian rule in 1812, but still home to a sizeable Romanian speaking population) reunited with Romania; the historical event is referred to ever since as "The Great Union".

6 The work premiered in Cluj on the $29^{\text {th }}$ of June 1958; stage director: Anghel I. Arbore, conductor: Alexandru Taban, scenery and costume design: Valer Vasilescu, Roman Morawsky: master of ballet, conductor of the choir: Kurt Mild. Cast: Ciprian - Alexandru Racolța, Vasile Șildan, Berta Gorgon - Stella Simonetti, Elena Vătafu, Martha Roth - Livia Liseanu, Lya 
pp. 828-829); his mother, Constanţa Ionescu, had been cast in the production, playing the part of Suzana, and she was with child at the time (during the whole period preceding the 2018 premiere, her son would refer to the character previously played by his mother as Suzănica, a diminutive form of Suzana). In other words, the director absorbs, almost six decades later, the entire vibration of his parents' performance and restages it as a token of high esteem and gratitude.

\section{Staging and Reception of the premiere: 1957 and 2018}

As Octavian Lazăr Cosma stated in his Monography of the Romanian Opera House in Cluj (2010, p. 828), Let me sing! had been the only premiered work during the season of 1957-1958 and it proved itself a great success: "a generous staging, featuring numerous moments of dramatic intensity. There were plenty of comic situations, well highlighted in the theatrical directing" but, at the same time, the abundant cast of over 40 spoken and sung parts added a shade of massiveness and stodginess to the performance, featuring "crowded and overstuffed scenes" (Cosma, 2010, pp. 828-829), in spite of the cuts in the libretto, wisely operated by the theatre director.

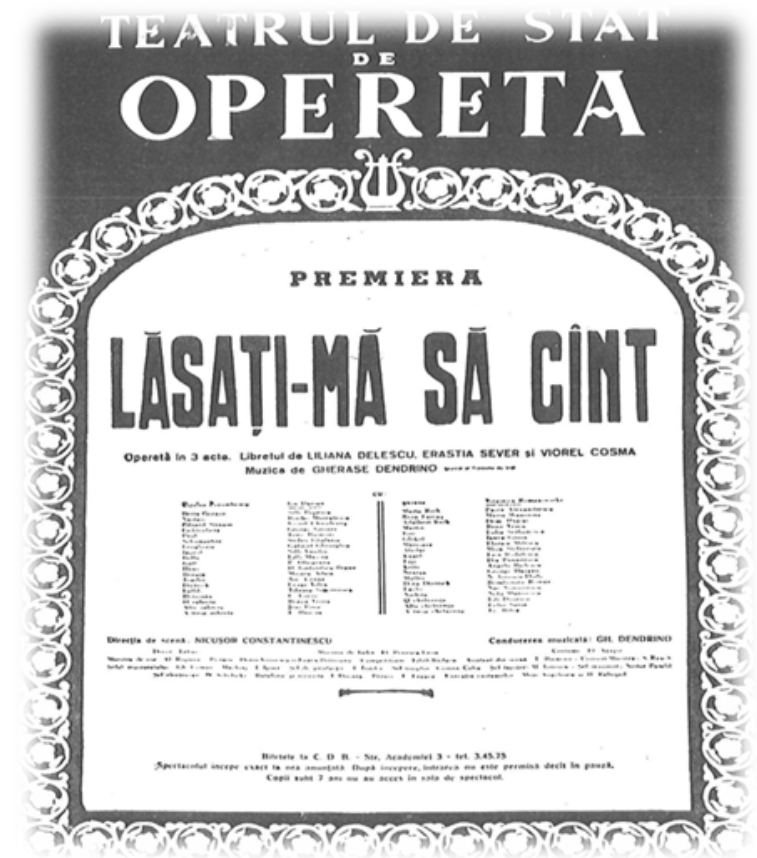

Fig. 1 Poster of the first premiere, The Operetta Theatre, Bucharest, 1954

The new production witnessed another four performances during the same season, which was already close to the end at the time of the premiere, and another almost 30 performances during the next season, confirming the success

Mărcuș-Anca, Suzana - Constanța Ionescu, Nastasi - Corneliu Fânățeanu, Constantin Drăghici, Eduard Strauss - Ion Piso, Martin - Traian Popescu, Ion Budoiu. 
of the premiere, the operetta being kept in the repertoire of the Romanian Opera House in Cluj for more than three decades, until a few years after the Revolution (1989).

Sixty years later, in 2018, the difficulties and pitfalls preceding the premiere are strikingly similar to those Ciprian Porumbescu himself encountered in 1882 with the staging of his operetta, a set of events which also constitute the plot of Dendrino's operetta. Thus, in spite of programming the premiere on the $25^{\text {th }}$ of May, financial distress of the Opera House and the lack of 'sprint' of the Ministry of Culture, which was to ensure the funds, imposed that the artists ${ }^{7}$, as well as the collaborators, together with the stage director, engage in this project for several months without wages; moreover, the premiere had to be postponed for the next season, following that the three performances of May and June 2018 to be designated as avant-premiere, each time being sold-out.

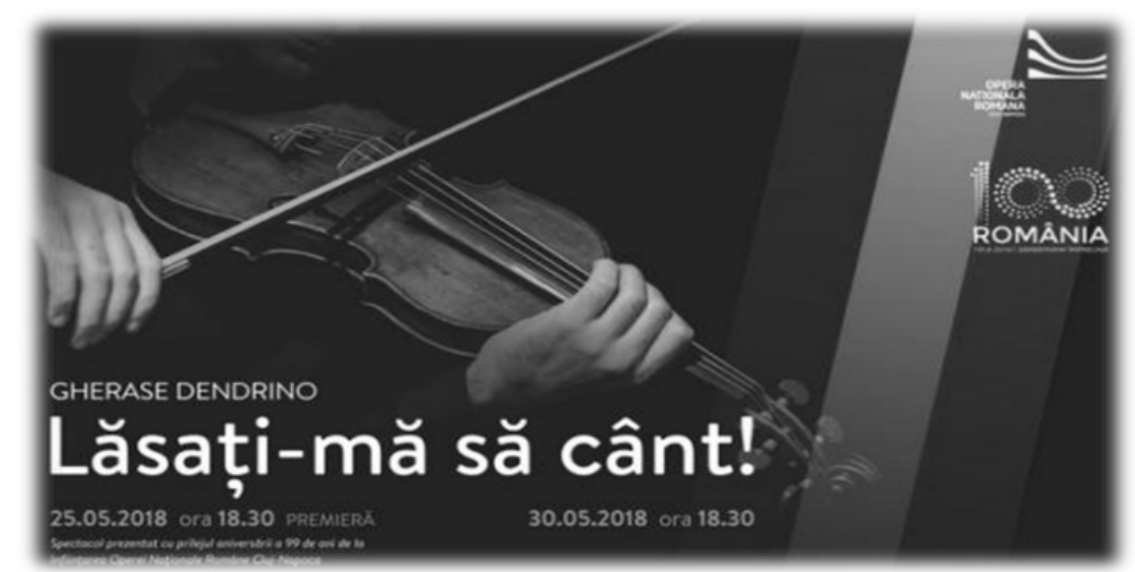

Fig. 2 Poster of the 2018 revival,

The Romanian National Opera House, Cluj-Napoca

\section{Characters and Plot}

Let us uncover the complicated threads of the plot of Dendrino's operetta: the story revolves around young composer Ciprian Porumbescu, resident in Brașov $^{8}$ as a music teacher at the Andrei Șaguna High School, as well as

${ }^{7}$ Cast of the premiere in 2018: Conductor: Adrian Morar, Stage direction: Cătălin Ionescu Arbore, Scenery and costume design: Adriana Urmuzescu, Choreography: Felicia Șerbănescu, Conductor of the choir: Emil Maxim, Ciprian Porumbescu - Cristian Mogoșan, Bertha Gorgon - Diana Gheorghe, Martha Roth - Diana Țugui, Suzana - Iulia Merca, Nastasi - Bogdan Nistor, Eduard Strauss - Tony Bardon, Contele de Lichtenberg - Petre Băcioiu, Martin Cristian Bogdan.

${ }^{8}$ Braşov: city in the central part of Romania; by the end of 19th century it was populated mainly by Germans (Saxons) and Romanians. 
conductor of the choral ensemble of St. Nicholas Church (as mentioned in the libretto). His dream is to compose and have performed a Romanian operetta and his fellow musicians and artists at the Theatre in town seem to follow his dream. The visit of an official representative sent from Vienna (as Transylvania was at the time a province of the Habsburg Empire) casts shadows on his project: Count Lichtenberg is instructed to dissolve the Association The Friends of Music, active in Brașov, and replace it with a new one, called Kultur und Musik, intended to comply with and to promote the Viennese style and repress Romanian national elements in music and opera performances, which were considered to be 'unsuited'. In his quest, the Count befriends the management of the theatre in town which, in its turn, bans the collaboration of Ciprian with the artists. The Count's new acolyte is Martin, editor-in-chief of the local gazette, whom he persuades to convince Ciprian to adapt his new operetta so as to replace peasants and folklore songs and dances by Viennese style characters and music. Martin also proposes to translate the libretto to German himself. The Count also allures Ciprian into accepting a new position as music inspector in the new Association, which builds up the first dramatic culmination of the plot, Ciprian's aria - Nu mă vând, nu sunt de vânzare! [I would not sell myself, I am not for sale!].

The second act witnesses a new major dramatic confrontation: seeing Ciprian's unbending attitude, the new Association Kultur und Musik management sets the date of its inauguration concert at the same day and hour as the New Moon premiere, making it impossible for the artists to perform in both shows. An outburst of fury on the part of Martin culminating in offending Ciprian by calling him a 'mere fiddler' draws to the latter's first tuberculosis crisis and, hence, Porumbescu's second great aria - Sărmane lăutar! [Poor fiddler!]. But, as in any operetta of great class, the atmosphere shifts radically and a new shade of hope arises when Ciprian's friends, former members of Friends of Music, decide together to perform his operetta by themselves, without any 'professional' help. It is particularly at this moment that composer Eduard Strauss, a descendant of the great Viennese composers' family and a dear friend and fellow colleague of Ciprian whom the latter had befriended during his studies in Vienna, offers to conduct the operetta. The second act concludes with the singing of the most celebrated chorus, New Moon, by Ciprian and his friends.

The final act, which was to be cut off and reworked by Dendrino, deals with a last dramatic conflict: Martha Roth, an artist at the theatre in love with Ciprian, flees from the Kultur und Musik performance, which results in its cancellation; she goes to Ciprian's premiere, in order to be by his side. She is searched for by the police, as her fleeing embarrassed the Count and the audience, and the police officer threatens to cancel New Moon too, until she is to be found. But Bertha, the one Ciprian loves deeply but cannot marry due to 
her father's refusal, comes from far away to save him and his premiere, which takes place in the background, as one can hear the applause from backstage. The performance is a great success, featuring as artists amateur singers in the concert hall of the high school, and having as audience friends, peasants from the surrounding villages, etc.

\section{Layers of significance}

\subsection{Historical and political context then and now}

Might that be the epitome of the triumph of amateurism over professional singing and performing? The triumph of the Romanian operetta featuring peasants over the Viennese operetta showing glamorous crinolines, ballrooms full of mirrors and chandeliers and counts and countesses? Nowadays, we wouldn't surely think in those terms. Operetta is a musical staged genre invented and traditionally linked to Vienna, so who would ever dare today to attempt to criticize the authenticity of Count Lichtenberg's quest and opinion? $\mathrm{He}$ is merely trying to preserve the values of his own culture, who is after all, a subject of the Empire. Meanwhile, the friendship full of mutual admiration between Eduard Strauss and Ciprian Porumbescu (which seems a historical fact) is intended to calm down the somehow 'anti-Vienna', 'anti-occidental' or 'anti-European cultural values' tone, which can be traced throughout the libretto.

As for the 'amateurism' of Ciprian's friends, who gave each a helping hand in the pursuit of his dream, one can just accept the original meaning of the term: as stemming from the Italian verb amare - to love, amateurs being for the most part of the history of music the main performers and being designated as loving art and beauty.

\subsection{Communist cultural ideology and "fitting in" the content}

If we have discussed the original content of the libretto in the previous subchapter, it is now the place to understand what sort of impact this content would have had during Dendrino's time, concerning the cultural, social and even political perspective.

In this respect, let us try to depict those times, precisely the 1950 s of the last Century: firstly, we should envision them through the lens of the musicology of the time; secondly, in view of the Romanian post-communist musicological research concerning the post-war period. Octavian Lazăr Cosma, again, mentions, in 1962 (short of a decade after the first premiere of Let me sing!), amateur ensembles' cultural and musical activities in factories or in newly industrialized towns, staging works of Romanian composers. He thus illustrates, using the ideological-communist language of the time, the prevalence of amateurism over those of professional skilled performances, belittling the importance of the elites in musical life: "Workers in Reșița [a 
town in South-Western Romania] have recently staged the operetta Let me sing! by Gherase Dendrino. The artistic ensemble of the Railroad in Cluj has presented to the audience the national operetta in one act La seceriş. [The harvest] [...] by Tiberiu Brediceanu. The artists of the House of Culture in Râmnicu Vâlcea [another southern town of Romania] have played in the operetta New Moon by Porumbescu. This illustrates the continuous rising of the artistic level of the proletary artists, the passion and interest which they invest in the treasure of classical and contemporary music, performed with great courage and skill." (Cosma, 1962, p. 140) He even brings up, as a strong argument in supporting his idea, the unprecedented development of Romanian culture through the grounding, even in small towns, by the foundation of philharmonic orchestras and music schools etc., taking as an eloquent example the south-eastern town of Galați (!).

But the harsh reality concerning the opera and the operetta of the time is profoundly different, as described in 2002 by the Romanian musicologist Speranța Rădulescu: in what rendering the truth is concerned, operetta performances hardly ever take place during the post-war decades in the seasons of the few Opera Houses across the country; the solely operetta-specialised theatre is in Bucharest. After the instalment of the communist regime, few Romanian operettas are performed: Lysistrata and Lăsați-mă să cânt [Let me sing!] by Gherase Dendrino, Plutașul de pe Bistrița [The ferryman on Bistritza River] by Filaret Barbu. Among the foreign titles, some musicals as West Side Story by Leonard Bernstein and My Fair Lady by Frederick Loewe are performed. The audiences are "of average condition, striving to install themselves on much more comfortable social platforms" (Rădulescu, 2002, p. 113). In such conditions, the operetta becomes obsolete, "the universe of sweettaste day-dreaming which it proposes no longer complies with the sensibility of the contemporary audiences" (Rădulescu, 2002, p. 114). Such observations are also stated in Valentina Sandu-Dediu's musicological volume concerning the evolution of Romanian music after 1944 (2002), who describes in depth the cultural and political context of the time.

There is an overlap of this climate of dissolution of the genre with the time of the first premiere of Dendrino's operetta. One can scarcely listen to mere arias and duets that had made their day in the past. If it did happen, it would have been in concerts rather than on stage which consequently would have resulted in their being cut off from the musical and dramatic context they had previously fitted. It was, indeed, the only way for these musical pages to be made noticeable for the broad audience, amongst them some of Dendrino's operetta, such as the aria and duetto Te iubesc, draga mea! [I love thee, my beloved!], the aria Sărmane lăutar [Poor fiddler], and echoes of the student's choruses or of the most widely known chorus New Moon, all of them originally composed by Porumbescu and remade by Dendrino. 


\subsection{Hypotheses of success in 1954}

Despite the slow extinction of the genre, the undoubted success of the premiere in 1954 generates multiple hypotheses. The first and most plausible one is that some aspects concerning the content of the plot are conveniently superposed to the Stalinist ideology of the time: for example, that amateurs are better than professionals, music for the masses, performed by the masses, being one of the ideals of the soviet communist ideology, adapted for the Romanian cultural context. Thus, the ideological wave coming from Vienna gets into collision with promoting subjects of Romanian cultural inheritance, along with the use of traditional music and dance. In this respect, when Ciprian is ironically and condescendingly asked by the Count with whom he had studied composition, he promptly answers that his master in composition is the Romanian people, meaning the Romanian folklore.

Another possible answer to the operetta's success might be the fact that Gherase Dendrino was, at the time, the main conductor at the Operetta Theater in Bucharest. Apart from the fact that he held a key-role in promoting his own work, he was also in the position of ensuring plenty of rehearsal-time, the best cast, making sure that his work would be performed at the highest standards possible and according to his own interpretative concept.

A third possible answer would be the plot, which generally follows the biography of the composer and the historical truth, but lets aside his premature death, a few months after the premiere and the unresolved love story with Bertha Gorgon; the libretto however, turns to a happy-ending.

The fourth hypothesis could be the remaking of the most beloved scores of Ciprian Porumbescu (Imnul studenților [The Students' Hymn], Balada pentru vioară [The Ballad for violin], which he obsessively quotes as a leitmotif along the score, the arias previously cited, choral pages as Haideți, haideți! [Let's go, let's go!] and Crai nou [New Moon] in the second act, or even the military band music from the same second act, all of them rigorously cited by Dendrino in the score as originally written by Porumbescu). They must have been a guarantee of success, a starting point for Dendrino to construct a musical love story full of verve and humour, but also outbursts of dramatic accents.

Finally, it is worth taking into account the key-role of the patriotic song as a genre, which had been promoted by Ciprian Porumbescu in the historical context of the struggle for the Union of the Romanian Principalities during the second half of the $19^{\text {th }}$ Century. This consistent repertoire of choral works has also been 'confiscated' by the communist ideology concerning culture and music and reoriented in order to serve new purposes. Unfortunately, we have no knowledge whether Dendrino foresaw or even was aware of this danger when he used some of the patriotic melodies in his operetta and, subsequently, Corul studenților [the Students' Chorus] became one of the most widely known 
communist songs, with new lyrics, related to the returning of the celebration of the International Workers' Day.

\subsection{Success in 2018}

A guaranteed success was made possible at the first premiere, and some or all the hypotheses above could have more or less contributed to it. But what could have secured the success nowadays, when this operetta does not serve any ideology anymore? As in the previous subchapter, we will try to provide some answers.

First, it is important to take into account the shift of the modern staging of the work from the ideological prevalent aspect to the aesthetic and ethical vectors of the unfolding of the story. Indeed, Ciprian Porumbescu has been a symbol of the Romanian musical heritage of the $19^{\text {th }}$ Century, and his status, depicted in this operetta, grants him honour: he is and remains up to the end surrounded by his friends precisely for his ethical values and for being a composer of honest gifts, determined to bring renewed value to the Romanian cultural heritage, to bring to light the rural life of Romanian peasants and to decode their spirituality, by a genuine European musical genre : the operetta.

Secondly, one may consider the reinvestment with new significance of the patriotic song as a choral genre, thoroughly distorted by the communist regime and, perhaps, its redefining as an iconic moment in the Romanian culture and history, with a certain impact in the development of the successive stages of later composition. The nowadays audience would not link it anymore to propaganda, but they could rather re-evaluate it considering its previous function and content. And, maybe, its reintegration in the choral repertoire during the last decades, seeking for another type of feed-back from the audience, compared to the last decade of communism, could have added to the success of the 2018 premiere.

Thirdly, the value of the score itself must be taken into account. Gherase Dendrino studied composition at the Bucharest Conservatory under Dumitru Georgescu-Kiriac and Alfonso Castaldi ${ }^{9}$, becoming soon a great master of orchestration, a fact that could be easily depicted from the first pages of the score. Moreover, his conducting activity deepened his skill of using voices and instruments and encouraged him to search for new and refreshing timbral combinations, nevertheless efficiently and skilfully. As a composer, he was able

${ }^{9}$ Dumitru Georgescu-Kiriac (1866-1928) and Alfonso Castaldi (1874-1942) were two of the leading figures in the field of Romanian composition and conducting, respectively, during the first half of the last century; they took teaching positions as well, tutoring generations of young composers at the Bucharest Conservatory. Composer of choral music and a refined conductor, Kiriac had studied first in Bucharest, then in Paris, at the National Conservatory and at the Schola Cantorum, under Charles-Marie Widor and Vincent d'Indy. In turn, Castaldi, studied in Napoli under Umberto Giordano and Francesco Cilea, two of the great masters of verismo. Both Kiriac and Castaldi valued the European musical heritage and passed it on to their disciples. 
to picture in sound a whole diversity of worlds and atmosphere: from the Viennese waltz of the salons of the Empire capital, as in Eduard Strauss' aria in the first act, to the instrumental Romanian folklore, as in the introduction to the aria with choir Mugur, mugurel [Little bud of flower], or even the vocal folkloric song, mainly in the duets of Suzanna and Nastasi. One could also mention the song in the romance manner, as in the duet of Martha and Bertha in the third act and the cabaret-like quintet of artists in the first act. The combination of styles in Dendrino's work is always genuine and accomplished. The melodic motive of the Balada pentru vioară [Ballad for violin] accompanies Ciprian's destiny, since he was in real life, a skilled violinist. The choral writing is subtle as well, efficient and colourful, whereas the soloistic parts require both lyricism and expressive force (mostly those of Ciprian, Martha and Bertha).

Not in the least, the work marvels both audience and researchers through its fine accordance to the spirit of the Viennese operetta: the secondary comic couple of characters - Suzana and Nastasi -, the use of the children's choir in the scene of the Count in the first act and of a variety of vocal ensembles all over the unfolding of the score (the quintet of artists, the trio of maids, the trio of peasants and the trio of waitresses). There is also a certain element of melodrama in the work, mostly in the dialogue scenes, which points to the operetta as well. One could also mention the lightness of the melodic lines, the mandatory happy ending, full of poetry, when Suzana sees the Moon arising and the tutti ensemble sings Crai nou [New Moon] once again, the most celebrated page of music ever to be composed by Porumbescu.

\section{Conclusions}

The success of audience of a work is not permanently guaranteed across the ages and the history of music proves that repeatedly. Some works gain success as soon as they are performed and lose it like the fire of a candle. Some others get to the heart of the audience decades, or even centuries after having been composed. The very values that the past once put into light could be easily overstepped by new, different or even divergent values. And, vice versa, that what a period of time promotes as incontestable values, another period of time would neglect; instead, it might propose a new set of values. Society, politics and musical trends change, but ethics and aesthetic values are perennial, and art that was once 'confiscated' by political propaganda, although at risk of being confiscated again, survives through its perennial values. Thus, every revitalization of a work of the past implies a coefficient of risk, but with this work, it was worth the risk.

Considering the aforementioned, the revitalization of such a musicaldramatic work has been proven to be purposeful, in a centennial anniversary year when numerous cultural projects, of more or less significance, have been 
proposed to the audience. In 2003, the Operetta Theatre "Ion Dacian" had also revived the work and later, in 2015, the students of the National University of Music in Bucharest successfully achieved a remake, with piano accompaniment. Thus, it was not particularly the novelty of such an endeavour to provide the success in 2018 , but the score itself.

\section{References}

Cosma, O. L., (2010). Opera Română din Cluj [The Romanian Opera in Cluj], 1 (1919-1959). Țărmure, G. (Ed.). Bistrița: Editura Charmides.

Cosma, O. L. (1962). Opera românească [Romanian Opera]. București: Editura Muzicală.

Cosma, V. (1999, 2005). Muzicieni din România. Lexicon biobibliografic [Musicians from Romania. A biobibliographical lexicon], 2 (C-E), VIII (P-S). București: Editura Muzicală.

Sandu-Dediu, V. (2002). Muzica românească între 1944-2000 [Romanian music between 1944-2000]. București: Editura Muzicală.

Rădulescu, S. (2002). Peisaje muzicale în România secolului XX [Musical landscapes in $20^{\text {th }}$ Century Romania]. București: Editura Muzicală.

Cosma, O. L. (2010). Opera Română din Cluj [The Romanian Opera in Cluj], I (19191959). Țărmure, G. (Ed.). Bistrița: Editura Charmides.

Cosma, O. L. (1962). Opera românească [Romanian Opera]. București: Editura Muzicală.

Cosma, V. (1999, 2005). Muzicieni din România. Lexicon biobibliografic [Musicians from Romania. A biobibliographical lexicon], II (C-E), VIII (P-S). București: Editura Muzicală.

Dendrino, G. (1956). Lăsați-mă să cînt! Episod din viața compozitorului Ciprian Porumbescu. Reducție de pian [Let me sing! An episode from the life of Ciprian Porumbescu. Piano reduction]. Libretto: Delescu, L. \& Sever, E. \& Cosma, V. București: Editura de Stat pentru Literatură și Artă.

Sandu-Dediu, V. (2002). Muzica românească între 1944-2000 [Romanian Music between 1944-2000]. București: Editura Muzicală.

Rădulescu, S. (2002). Peisaje muzicale în România secolului XX [Musical landscapes in $20^{\text {th }}$ Century Romania]. București: Editura Muzicală. 